\title{
The Competence of Junior High School Economic-Social Studies Teachers in Research
}

\author{
Sukidjo $^{1}$ \\ ${ }^{1}$ Faculty of Economics, State University of Yogyakarta, Indonesia \\ Correspondence: Sukidjo, Faculty of Economics, State University of Yogyakarta, Indonesia. Tel: \\ 62-812-275-3674. E-mail: sukidjo@uny.ac.id
}

Received: June 11, 2015

doi:10.5539/jel.v4n3p136

\author{
Accepted: July 4, $2015 \quad$ Online Published: August 11, 2015 \\ URL: http://dx.doi.org/10.5539/jel.v4n3p136
}

\begin{abstract}
The objective of this study was to determine how different is the competence of between Junior High School Economic-Social Studies teachers in Indonesia, especially Java and outside of Java. The subjects of this study were teachers who participated in Curriculum 2013 dissemination activities carried out by the Directorate of Elementary and Secondary Education, Department of Education and Culture. Respondents were selected by simple random sampling, namely the Junior High School Economic-Social Studies teachers from Java and outside of Java. Instruments used to collect the data were in the form of questionnaires and documents. The data were analyzed using quanitative analysis. Results showed that the ability of teachers in Indonesia for research have not been evenly distributed proportionally. Junior high school teachers who served in Java have the ability to research better than the teacher outside Java. In Java which has a more complete educational facilities, teacher is easier to access books, research reports, experts, and other resources. The research competence of High School Economic-Social Studies teachers in Java have higher levels of competence of theoretical mastery, cognitive ability, and technical ability than teachers in outside of Java.
\end{abstract}

Keywords: teachers competence in research

\section{Introduction}

Human resource is one of the factors that determine the success of national development. If the population is high, but the quality is low, it will then become an obstacle to development, whereas if the quality of population is high, it will facilitate the implementation of the development. Therefore, every country always tries to improve the quality of its people through education. The Indonesian Law No. 20 on National Education System says "education is a conscious and planned effort to create a learning atmosphere and a learning process so that the learners can actively develop their potentials to obtain the strength in spiritual religion, self-control, personality, intelligence, noble character, and skills that are needed by the learners themselves, the people, nation and state as well" (Law No. 20 in 2003). Education then functions to improve the knowledge, attitudes, and skills.

The availability of qualified human resource is very important in national development. Qualified human resource will be able to develop science and knowledge, create technology useful in processing the natural resources in order to increase the national income and welfare of the community. Therefore, qualified human resource can be seen as one key to the progress of a country.

Improving the quality of human resource requires education. Discussing education issues cannot be separated from the role of the teacher. Teacher is one urgent component in improving the quality of education. Qualified education will generate graduates who have high ability and skills as well as a positive attitude towards national development.

\section{Literature Review}

Teachers play a very important role in education, especially in formal education. Teachers will determine the success of education throughout the learning process. Even teachers are seen as the most influential component in creating the good process and qualified outcomes of education (Khotijah, 2013, p. 91). Considering such an important role the teachers play in improving the quality of human resources, teachers are then required to always improve their quality and competence to be professional teachers. Nevertheless, the quality and competence of teachers in Indonesia have not yet been in line with the expectations. The quality of teachers is 
not satisfying, as admitted by the Education Minister and proved from the low results of the initial competency test. The results of the initial competency test of 281,016 teachers from kindergartens to high schools/vocational schools show the average value of only 42.25, and the scores of the supervisors are even lower (Kompas, 2012). The low quality of teachers even also took place in the schools which were formerly known as the Pilot School of International Level. Based on data from Center of Reseach and Development of Culture and Education Ministry, only 1 to $2.9 \%$ of internastional school teachers from Biology, Mathematics, Chemistry and Physics subjects could achieve the English language competence which meet the standards as academic language with a minimum score of 800 ; and surprisingly enough, only $5.6 \%$ of English teachers who get the score of 800 and above (Suwarjo, 2013, p. 435).

In order to improve the quality and competence of teachers, the government has actually organized various of activities which include upgrading, training, seminars, workshops, as well as providing lots of opportunities for teachers to continue their study to master and doctoral degrees. The importance of training for continual updating and improvement was one source of human motivation at work was intrinsik motivation, desire to grow, learn and develop oneself (Karia, 2000, pp. 66-76). It is similar to research's Rotich that capacity building is highly correlated to hwead teachers' competency in primary school manajement (Rotich, 2014, pp. 131-132). In addition, the professional organizations of teachers, for example the Association of Teachers of Subject Matters and Association of School Principals have functioned actively to improve the teachers' competence and to solve various problems of education in general. The government is fully aware that many teachers do not have time to improve their quality and competence because they are very busy doing additional activities to improve their revenue. In other words, welfare is still a factor needs considering in an effort to improve the professionalism of teachers.

The issuance of Law No. 14 in 2005 on Teachers and Lecturers is a clear evidence of the seriousness of government to improve the professionalism and welfare of teachers. Based on Law No. 14 in 2005 a teacher is positioned as a dignified profession, so teachers are considered professional educators. In Article 1 of Law No. 14 in 2005, it is clearly stated that the teacher is a professional educator with a primary task of educating, teaching, guiding, directing, training, assessing and evaluating students in early childhood education in formal education, elementary education and secondary education. Furthermore, in article 4 , it is stated that the position of teachers as professionals functions to enhance the dignity and role of the teacher as a learning agent serving to improve the quality of national education (Law No. 14 in 2005). As professionals, teachers are then required to always improve their competence, so as to guarantee that the implementation of teaching-learning process will be better, which in turn can produce more qualified graduates. If all teachers are able to implement good learning process, the quality of graduates and the quality of national education will increase as well.

Based on Law No. 20 in 2003 on National Education System, the Law No. 14 in 2005 on Teachers and Lecturers, and Government Regulation No. 19 in 2005 on National Education Standards, it is clearly stated that teachers are professional educators. With the implementation of Law No. 14 in 2005, teachers have two positions, namely as professional workers and as agents of learning. As professional workers, teachers work to improve the dignity of people; while as agents of learning, teachers serve to improve the quality of national education. The statement "teachers as professionals" implies that the teacher's job can only be done by someone who have already possessed the academic qualifications, competence and educator's certificate. The academic qualification required for teachers is minimum an undergraduate level of S1 or D4 (Bachelor's Degree). As agents of learning, teachers are demanded to play their role as facilitators, motivators, leaders, catalysts and evaluators. As professionals, teachers will be able to carry out the learning process in the spirit of being a model in front, motivating in the middle, and supporting at the back. This implies that teachers must be able to be good models, able to raise the motivation of the learners, and able to provide protection and responsibility.

In Law No. 14 in 2005, it is stated that competence is a set of knowledge, skills and behaviors that should be owned, understood, and mastered by a teacher or lecturer in performing their duties as professionals. The competence of teachers as agents of learning includes pedagogical competence, professional competence, personal competence and social competence. Pedagogical competence is the ability of teachers to manage learning, including mastering the learning theories, the ability to understand the learners, and the ability to perform the learning process. Professional competence is the teacher's ability to master the subject matter broadly and deeply. Personal competence is the ability of the teachers to reflect as a person who is steady, noble, wise and authoritative and able to be a model for their students. While social competence is the ability of teachers to establish communication and interaction effectively with their students, their fellow teachers, the learners' parents as well as other people in the surrounding community. Teachers' professionalism is proved by certificates obtained through portfolio assessment or education. In facing the 21 st century, teachers are required 
to have high professionalism. In the 21st century, every teacher is a professional in an open society and a competitive profession (Tilaar, 1999, p. 2840). The characteristics of professional teachers are, among others, having a strong foundation of knowledge, based on individual competence, having a system of selection and certification, able to manage collaboration and healthy competition among peers, having high professional awareness, and having individual militancy (Suyanto, 2007, p. 4). A recent study conducted by Widoyoko (2010) shows that high school teachers in Yogyakarta Special Province have a satisfying level of competence. From the research, it is known that the level of competence of high school teachers in the Yogyakarta is higher than the level of competence of high school teachers in Central Java.

As professionals, teachers should always improve their competence so as to obtain better professionalism. In connection with the efforts to improve professionalism of teachers, the government through the State Minister of Controlling State Administration and Bureaucratic Reform, issued a regulation called Permeneg PAN \& RB No. 16 in 2009 on Sustainable Professional Development (Depdikbud, 2009). In Permeneg PAN \& RB, it is mentioned that teachers are required to conduct Sustainable Professional Development, which consists of self-development, scientific publications, and innovative work. Self-development activities are intended to improve the professional competence, in the form of enriching and deepening materials in the specific field of study. Self-development can be carried out through pursuing further studies (masters/doctors), seminars, workshops, and actively participating in various activities organized by the teacher professional organization such as Association of Teachers of Subject Matters. The activities of scientific publications include a presentation in academic forums, scientific publication of research results, the publication of textbooks, books enrichment, and teachers guide. While innovative work activities include: finding appropriate-practical technologies, creating works of art, making props/model for practicum and following the development of guidelines and a standard setting up questions. PKB is implemented as an effort to realize a professional, dignified, and prosperous teachers so as to achieve national education goals. One of the activities undertaken for professional development of teachers is implementing the scientific research.

Scientific research is systematic, contolled, empirical. amoral, public, and critical investigation of natural phenomena. It is guided by theoryand hyphotheses about the presumed relations among subphenomena (Kerlinger, 2008, p. 14). The scientific research is systematic and controlled, it mean investigator critical confidence in reseacrh outcome. Scientific research obervations are tightly disiplined. Scientific research is empirical, it mean to belief something, investigator must be checked against objetive reality. Scientific research is a moral evaluation, it mean the result are neither consider bad nor good, but in term of validity and reliability.

In order to improve competence in research, every teacher must master the theoretical foundation and research methods so that teachers will have research competence. Ability to be owned by a teacher in conducting research is the ability to discover and formulate a problem, establish hypotheses, collect data, analyze the data and draw conclusions based. For the purposes of analyzing the data, the teachers must have skills in data processing, have mastered the skills in statistics and data processing techniques either manually or using a computer. The teachers must have mastered the steps for research, includes a preliminary study, formulating the problem, formulating hypotheses, choosing the research design, determining variables, preparing instruments, collecting data, analyzing the data, draw conclusions and write a research report (Arikunto, 2012, p. 17).

This study was intended to find evidence related to the difference between the research capabilities of High School Economic-Social Studies teachers in Java and outside of Java and the research capabilities of High School Economic-Social Studies teachers in Java and outside of Java.

\section{Research Method}

This study constituted a survey research and was aimed to picture the competence of junior high school economic-social studies teachers in Indonesia, especially in Java and outside of Java in conducting research. Indonesia has more than seventeen thousand of islands and Java is one of those in which Indonesian government centre is located. It has many educational facilities such as a library, bookstores, and various educational equipment. Teachers here can obtain books and research reports research easily, while the resources in outside of Java is relatively less.

Simple random sampling method was used to determine the samples. The total samples in this study were 96 teachers comprised of 58 teachers from Java and 38 teachers from outside of Java. The data were collected using questionnaires and documentation, and then analyzed using quantative analysis. To facilitate understanding and interpretation, the data were presented in tables and percentages. To know the differences between the level of competence of High School Economic-Social Studies teachers in Java and those in outside of Java, quantitative analysis was used by the multivariate analysis (Manova) and the univariate analysis (Anova). 


\section{Results}

Based on the collected data it is known that $79 \%$ of junior high school Economic-Social Studies teachers in Java aged 31-50 years, while 7\% were the young teachers of $25-30$ years, and the rest (14\%) aged 51-60 years. On the other hand, junior high school teachers in outside of Java, those aged 31-50 years old were 79\%, those aged 25-30 years were $8 \%$, and those aged 51-60 years were $12 \%$. Therefore, in terms of age, the composition of junior high school teachers in Java are relatively similar to the junior high school teachers in outside of Java. For more details, the description of junior high school teachers in Java and junior high school teachers in outside of Java based on age is presented in Table 1 below:

Table 1. Description of teachers based on age

\begin{tabular}{cccccccc}
\hline \multirow{2}{*}{ No } & Age & \multicolumn{2}{c}{ Java } & \multicolumn{2}{c}{ Outside of Java } & \multirow{2}{*}{ Total } & \multirow{2}{*}{$\%$} \\
\cline { 3 - 6 } & & Qty & $\%$ & Qty & $\%$ & & \\
\hline 1 & $25-30$ years & 4 & 6.89 & 4 & 10.53 & 8 & 8.33 \\
2 & $31-35$ years & 10 & 17.24 & 13 & 34.21 & 23 & 23.96 \\
3 & $36-40$ years & 8 & 13.79 & 9 & 23.68 & 17 & 17.71 \\
4 & $41-45$ years & 20 & 34.48 & 6 & 15.79 & 26 & 27.08 \\
5 & $46-50$ years & 8 & 13.79 & 2 & 5.26 & 10 & 10.42 \\
6 & $51-55$ years & 7 & 12.06 & 2 & 5.26 & 9 & 9.38 \\
7 & $56-60$ years & 1 & 1.72 & 2 & 5.26 & 3 & 3.13 \\
\hline & Total & 58 & & 38 & & 96 & 100 \\
\hline
\end{tabular}

Source: Research Data

When viewed in terms of rank/class, as many as $57 \%$ of junior high school teachers in Java have achieved the $\mathrm{rank} / \mathrm{class} \mathrm{IV} / \mathrm{a}$ and IV/b, those with rank/class III/c-III/d are $14 \%$ and rank/class III/a-III/b are $24 \%$. While for junior high school teachers in outside of Java, those with rank/class IV/a are $14 \%$, and no one has the rank/class IV/b. Teachers with rank/class III/c-III/d are $45 \%$, and teachers with rank/class III/a-III/b are $42 \%$. It can be said that, in terms of rank/class, junior high school teachers in Java have higher rank/class than junior high school teachers in outside of Java. Data of teachers based on rank/class are presented in Table 2 below:

Table 2. Description of teachers based on rank/class

\begin{tabular}{|c|c|c|c|c|c|c|c|}
\hline \multirow[t]{2}{*}{ No } & \multirow[t]{2}{*}{ Rank } & \multicolumn{2}{|c|}{ Java } & \multicolumn{2}{|c|}{ Outside of Java } & \multirow[t]{2}{*}{ Total } & \multirow[t]{2}{*}{$\%$} \\
\hline & & Qty & $\%$ & Qty & $\%$ & & \\
\hline 1 & III a & 7 & 12.06 & 6 & 15.29 & 13 & 13.54 \\
\hline 2 & III b & 10 & 17.24 & 10 & 26.32 & 20 & 20.83 \\
\hline 3 & III c & 6 & 10.34 & 14 & 36.84 & 20 & 20.83 \\
\hline 4 & III d & 2 & 3.45 & 3 & 7.89 & 5 & 5.21 \\
\hline 5 & IV a & 31 & 53.45 & 5 & 14.29 & 36 & 37.50 \\
\hline \multirow[t]{2}{*}{6} & IV b & 2 & 3.45 & 0 & 0 & 2 & 2.08 \\
\hline & Total & 58 & & 38 & & 96 & 100 \\
\hline
\end{tabular}

Source: Research Data

Viewed from whether they have ever conducted research or not, 31 people (53\%) junior high school teachers in Java claimed to have done research, with the details of 13 people (22\%) are teachers who have the rank III, and 18 people (31\%) of teachers have the rank IV. As for the teachers in outside of Java, 4 people $(10.5 \%)$ claimed to have done research, all of whom were of rank III, and all teachers who are in rank IV have never done research. 
To measure the level of competence in conducting research, 60 statements are given as the elaboration of the six components in doing research, i.e., the components of: Theoretical Mastery Level, Cognitive Mastery Level, Technical Ability Level, Experience, Level of Difficulty and Supporting Factors. All the items/statements were prepared using the Likert scale model with four alternative answers. The obtained results are presented in Table 3 below:

Table 3. Level of competence of teachers in Java and in outside of Java

\begin{tabular}{llcccccc}
\hline \multirow{2}{*}{ No } & Aspect & \multicolumn{3}{c}{ Java } & \multicolumn{3}{c}{ Outside of Java } \\
\cline { 3 - 7 } & & High & Medium & Low & High & Medium & Low \\
\hline 1 & Theoretical Mastery Level & $13 \%$ & $87 \%$ & $0 \%$ & $0 \%$ & $87 \%$ & $13 \%$ \\
2 & Cognitive Mastery Level & $0 \%$ & $100 \%$ & $0 \%$ & $0 \%$ & $70 \%$ & $30 \%$ \\
3 & Technical Ability Level & $0 \%$ & $86 \%$ & $14 \%$ & $0 \%$ & $29 \%$ & $71 \%$ \\
4 & Experience & $25 \%$ & $75 \%$ & $0 \%$ & $0 \%$ & $11 \%$ & $89 \%$ \\
5 & Level of Difficulty & $37 \%$ & $63 \%$ & $0 \%$ & $78 \%$ & $22 \%$ & $0 \%$ \\
6 & Supporting Factors & $64 \%$ & $36 \%$ & $0 \%$ & $36 \%$ & $64 \%$ & $0 \%$ \\
\hline
\end{tabular}

In order to maintain and improve the professionalism of teachers, the government requires that every teacher who has obtained certification should sustainably develop their profession. This was stated in governmend regulation on Sustainable Professional Development, which states that teachers are required to conduct Sustainable Professional Development. Even in the regulation, teachers who will be promoted to the rank/class of III/b are obliged to have one professional development work, for example educational research. However, although there has been a regulation requiring teachers to develop their profession through conducting a research, in reality, there are many teachers who have not yet carried out research for the improvement of teaching-learning process. This is true to both the teachers who served in Java and those in outside of Java. There are $47 \%$ junior high school teachers in Java who have never carried out educational research, and most of junior high school teachers in outside of Java (89.5\%) have not conducted educational research. Why have most of junior high school teachers in never done educational research? Their reluctance was due to the many obstacles that confront them in doing so. Following are the tables presenting a variety of internal and external obstacles faced by junior high school teachers in Java and in outside of Java in implementing educational reesearch.

Table 4. Internal obstacles faced by teachers in conducting research

\begin{tabular}{llcccc}
\hline \multirow{2}{*}{ No } & Internal Obstacles & \multicolumn{2}{c}{ Outside of Java } & \multicolumn{2}{c}{ Java } \\
\cline { 3 - 6 } & & Qty & $\%$ & Qty & $\%$ \\
\hline 1 & Lack of understanding about research & 28 & 78.68 & 8 & 23.79 \\
2 & Inability to find out problems & 1 & 2.63 & 2 & 3.45 \\
3 & Inability to formulate problems & 1 & 2.63 & & \\
4 & Inability to collect data & & & 2 & 3.45 \\
5 & Inability to analyze data & 4 & 10.53 & 5 & 8.62 \\
6 & Inability to write the report & 4 & 10.53 & 2 & 3.45 \\
\hline
\end{tabular}

Note. The number of teachers in outside of Java $=38$, in Java $=58$

Table 5. External obstacles in conducting research

\begin{tabular}{llcccc}
\hline \multirow{2}{*}{ No } & External Obstacles & \multicolumn{2}{c}{ Outside of Java } & \multicolumn{2}{c}{ Java } \\
& & Qty & $\%$ & Qty & $\%$ \\
\hline 1 & Limited references / bibliography & 12 & 31.58 & 2 & 3.45 \\
2 & Limited time & 15 & 39.47 & 11 & 18.97 \\
\hline
\end{tabular}




\begin{tabular}{|c|c|c|c|c|c|}
\hline 3 & Lacks of informants and supervisor & 2 & 5.26 & 3 & 5.17 \\
\hline 4 & Lack of institutional support & 2 & 5.26 & & \\
\hline 5 & Time synchronization with collaborators & & & 2 & 3.45 \\
\hline 6 & Language style and Reviewer Team & & & 2 & 3.45 \\
\hline 7 & Funding & & & 2 & 3.45 \\
\hline
\end{tabular}

Furthermore, to support the result descriptively, the researcher conducted statistical analysis using the multivariate analysis (MANOVA) and the univariate analysis (ANOVA). The results of those analyses are presented in the following Table.

Table 6. Descriptive statistics

\begin{tabular}{clccc}
\hline Research Aspect & \multicolumn{1}{c}{$\begin{array}{c}\text { Location of } \\
\text { Teachers }\end{array}$} & Mean & Std Deviation & N \\
\hline Theoretical Mastery & Java & 2,6594 & .33077 & 55 \\
& Outside of Java & 2.3133 & .44124 & 40 \\
\multirow{5}{*}{ Cognitive Ability } & Java & 2.5673 & .36871 & 55 \\
& Outside of Java & 2.2875 & .38907 & 40 \\
\multirow{5}{*}{ Technical Ability } & Java & 2.3818 & .40691 & 55 \\
& Outside of Java & 2.1750 & .37933 & 40 \\
\multirow{2}{*}{ Experience } & Java & 2.6477 & .39490 & 55 \\
& Outside of Java & 2.5063 & .51806 & 40 \\
\hline
\end{tabular}

Note. Score 1-4

From Table 6 above, it can be seen that the mean for all aspects of research (theoretical mastery, cognitive ability, technical ability and experience) for teachers in Java is higher than those of teachers in outside of Java. This is in line with and aso supports the findings presented in Table 3. To make sure whether there is a difference, the data were then tested with multivariate analysis (Manova), and the results are presented in Table 7 below:

Table 7. Multivariate tests

\begin{tabular}{|c|c|c|c|c|c|c|}
\hline Effect & & Value & $\mathrm{F}$ & Hypothesis df & Error df & Sig. \\
\hline \multirow{3}{*}{ Intercept } & Pillai's Trace & .984 & $1348.358^{\mathrm{b}}$ & 4.000 & 90.000 & .000 \\
\hline & Wilks' Lambda & .016 & $1348.358^{\mathrm{b}}$ & 4.000 & 90.000 & .000 \\
\hline & Hotelling' s & 59.920 & $1348.358^{\mathrm{b}}$ & 4.000 & 90.000 & .000 \\
\hline \multirow{9}{*}{ Location } & Trace & & & & & \\
\hline & Roy's Largest & 59.927 & $1348.358^{\mathrm{b}}$ & 4.000 & 90.000 & .000 \\
\hline & Root & & & & & \\
\hline & Pillai's Trace & .179 & $4.899^{b}$ & 4.000 & 90.000 & .001 \\
\hline & Wilks' Lambda & .821 & $4.899^{b}$ & 4.000 & 90.000 & .001 \\
\hline & Hotelling' s & .218 & $4.899^{b}$ & 4.000 & 90.000 & .001 \\
\hline & Trace & & & & & \\
\hline & Roy's Largest & .218 & $4.899^{\mathrm{b}}$ & 4.000 & 90.000 & .001 \\
\hline & Root & & & & & \\
\hline
\end{tabular}


Based on the result of multivariate testing above the Wilk's Lambda value is found 0.821 with $\mathrm{F}=4.899$ and $\mathrm{p}=$ 0.001 . Therefore, as the $\mathrm{p}$-value is less than 0.05 , it can be concluded that there are significant differences considering the theoretical ability, cognitive ability, technical ability and experience about the competence of research between teachers in Java and in outside of Java.

Since the multivariate analysis proved significant, it is then required to prove whether there is significant difference among each of the components. For this purpose, univariate analysis (ANOVA) was conducted, and the result is as follows:

Table 8 . Tests between-subjects effects

\begin{tabular}{clrrrrr}
\hline Source & Dependent Variable & $\begin{array}{c}\text { Type III } \\
\text { Sum of } \\
\text { Square }\end{array}$ & df & $\begin{array}{c}\text { Mean } \\
\text { Square }\end{array}$ & F & Sig. \\
& Theoretical Mastery & $2.773^{\mathrm{a}}$ & 1 & 2.773 & 19.104 & .000 \\
Corrected & Cognitive Ability & $1.813^{\mathrm{b}}$ & 1 & 1.813 & 12.728 & .001 \\
Model & Technical Ability & $.991^{\mathrm{c}}$ & 1 & .991 & 6.330 & 0.14 \\
& Experience & $.464^{\mathrm{d}}$ & 1 & .464 & 2.441 & .122 \\
& & & & & & \\
& Theoretical Mastery & 572.649 & 1 & 572.649 & 3944.595 & .000 \\
Intercept & Cognitive Ability & 545.804 & 1 & 545.804 & 3832.420 & .000 \\
& Technical Ability & 480.864 & 1 & 480.864 & 3072.987 & .000 \\
& Experience & 615.154 & 1 & 615.154 & 3239.941 & .000 \\
& & & & & & \\
& Theoretical Mastery & 2.773 & 1 & 2.773 & 19.104 & .000 \\
Location & Cognitive Ability & 1.813 & 1 & 1.813 & 12.728 & .001 \\
& Technical Ability & .991 & 1 & .991 & 6.330 & .014 \\
& Experience & .464 & 1 & .464 & 2.441 & .122 \\
\hline
\end{tabular}

Based on the results of the univariate analysis presented in Table 8 above, it can be seen that:

a. Differences in research theoretical ability between teachers in teachers Java and in outside of Java: the result of ANOVA shows $\mathrm{F}$ value of 19.104 with $\mathrm{p}<0.001$. It can be concluded that there is a significant difference between research theoretical ability of teachers in Java and in outside of Java, where teachers in Java have a better research theoretical ability than teachers in outside of Java.

b. Differences in research cognitive ability between teachers in Java and teachers in outside of Java: the result of ANOVA shows $\mathrm{F}$ value of 12.728 with $\mathrm{p}=0.001$. It can be concluded that there is a significant difference in research cognitive ability between teachers in Java and teachers in outside of Java, where teachers in Java have a better research cognitive ability than teachers in outside of Java.

c. Differences in research technical ability between teachers in Java and teachers in outside of Java: the result of ANOVA shows $\mathrm{F}$ value of 6.330 with $\mathrm{p}=0.016$. It can be concluded that there is a significant difference in research technical ability between teachers in Java and teachers in outside of Java, where teachers in Java have a better technical ability than teachers in outside of Java.

d. Differences in research experience between teachers in Java and teachers in outside of Java: the results of ANOVA shows $F$ value of 2.441 with $p=0.122$. Since the value is not significant, it can be concluded that there is no difference in research experience between teachers in Java and teachers in outside of Java.

\section{Discussion}

Based on the data presented in Tables 1 and 2, it is known that although the number and age composition of teachers in Java and those of teachers in outside of Java are relatively the same, but in terms of rank/class the teachers in Java are relatively higher than the teachers in outside of Java. The indicator shows that that $57 \%$ of 
teachers in Java has the rank group of IV, compared to only $14 \%$ of teachers in outside of Java. The majority (86\%) of teachers in outside of Java are still in the rank group of III. On the other hand, if seen from experience in implementing research, $53 \%$ of teachers in Java have conducted research, compared to only $11 \%$ of teachers in outside of Java. Such conditions will surely affect their level of competence in implementing research.

Based on data in Table 3, it can be seen that the level of research competence the junior high school teachers in Java is better than that of the junior high school teachers in outside of Java. This finding is in agreement with a study by (Widoyoko, 2005, p. 380) which concludes that the ability of teachers in Java to master the content material Java is $85 \%$, categorized as good, and $75 \%$ of the teachers have a high work ethic. Viewed in terms of experience in doing research, more than half of Java teachers have got experience, while teachers outside of Java are generally not experienced. Lack of experience is considered a factor resulting in low research competence for teachers in outside of Java. This is also in line with the findings of previous research which concluded that teachers who have ever conducted research will have higher the cognitive and technical abilities than those who have not experienced so (Sukidjo, 2014, p. 377).

The factors causing the different levels of research competence due to the different levels of understanding, where $78 \%$ of teachers in outside of Java admit that they do not understand a research, nor do they have enough time to conduct it because of the load work in teaching-learning activities as well as administrative tasks. To solve the problem, the teacher should be trained contonuously to improve their research competence. It was like the opinion of Karia (2000) and Rotich (2014).

This condition is exacerbated by the lack of reference for them to access in the forms of reference books as well as examples of research projects. Therefore, it is important for teachers to have research books, books on their specific field study and other facilities in order to improve their profession as competent teachers. If teachers have studied a lot of books concerning research and research, they will then be more competent in overcoming their incomprehension and lack of understanding about research, as well as the difficulties in data collection, data analysis, and report writing. Therefore, the school management as one institutions, especially the school principals, as well as the staff in Department of Education, need to provide support, facilities, and opportunities for the teachers to keep their motivation and eagerness to do the necessary activities for the development of their profession. Additionally, the low implementation of the research for teachers in outside of Java, can also result from the location of outside of Java which is quite far away from city, with its shortcoming in transportation system and infrastructure as well as inadequate electricity supply.

The tight schedule of teaching and other administrative duties is often said as the main reason why the teachers do not carry out the research. Teachers in both Java and outside of Java find it difficult to set aside some time to implement the research, because many of the teachers have to teach up to 30 hours a week, lecturing the students Besides the teachers still have to do some administrative work, such as writing lesson plans, designing as well as correcting assignments and exams. This condition is consistent with the results of research Badrun (2010, p. 470), that $82.5 \%$ of teachers have not been doing research due to the busyness of school activities and not used to writing and researching. Teachers are more interested in the seminar either at its own cost and expense of the school. On the other hand, there are some junior high school teachers in Java who has conducted some the research, but still they face lots of obstacles to do another the research. The main obstacle faced by these teachers is, among others, the difficulty to synchronize the time between the researcher and collaborators due to the teaching schedule for teachers is different from each other.

To find out which items of the aspects that the teachers have mastered and which items they have not, it is necessary to analyze each of the aspects. There are six aspects used to measure the level of competence controlled by the teachers, each of which will be formulated into 10 statements which then form the total 60 items. The six aspects are (1) the level of theoretical mastery; (2) the level of cognitive ability; (3) the level of technical ability; (4) experience in conducting the research; (5) the level of difficulty and (6) other supporting factors. Viewed from each aspect, the level of teachers' competence in doing the research can be described as follows:

As many as $13 \%$ of junior high school teachers in Java claimed to master the research theoretically in very high (very good) category, $87 \%$ were in category good, and no teacher was in category fair or poor. Teachers in Java has the very good theoretical mastery in the research especially in terms of the definition, characteristics, principles, and implementation stages of the research. Meanwhile, no junior high school teachers in outside of Java has either very good or good level in theoretical mastery, only $13 \%$ of teachers were in category fair and $87 \%$ in the category poor. The low level competence of the research theoretical mastery for outside of Java teachers lies in methods of data collection and data analysis. 
Based on the data above, it is known that the research theoretical mastery level is higher for junior high school teachers in Java than for those in outside of Java. The high competence of teachers in Java is in line with the research conducted by (Widoyoko, 2005, p. 380) which concluded that the ability of teachers in Java in mastering the content material was $85 \%$ in category good, $75 \%$ of teachers have high work ethic, while the ability of teachers outside Java was mostly relatively low.

Viewed from the aspect of Cognitive Ability level, it is known that all teachers in Java claimed to have cognitive ability in category fair, whereas in outside of Java, $30 \%$ of teachers stated to have poor cognitive ability, especially on formulating the research setting, determining techniques of analysis as well as writing reports upon completing the research. Based on these data, it is known that the level of cognitive ability for teachers in Java is higher than teachers in outside of Java. Viewed from the aspect of Technical Ability, $71 \%$ of teachers in outside of Java declare to have poor technical ability and only $29 \%$ are categorized fair. The low technical ability of outside of Java teachers is primarily related to the preparation of proposals, implementation of the research, and data analysis for both quantitative and qualitative. While for the teachers in Java, $86 \%$ claimed to have fair technical capability and only $14 \%$ said to have poor. Based on these data, it can be said that the level of the research technical ability is higher for teachers in Java than for the teachers in outside of Java. The big difference in the levels of theoretical mastery, cognitive ability, and technical ability between teachers in Java and teachers in outside of Java is likely due to the different levels of experience in implementing the research. Junior high school teachers in Java have tend to have at least an experience in doing a research, i.e., $88 \%$ have experience as the main researcher and $12 \%$ as the co-researcher, compared to only $11 \%$ of junior high school teachers in outside of Java who have experience in implementing the research, i.e., $75 \%$ as the co-researcher and $25 \%$ as the main researcher. This fact is in line with the research by Sukidjo $(2004$, p. 455; 2014, p. 377) which concluded that differences in experience affect the level cognitive ability in research.

Viewed from the aspect of other supporting factors, i.e., in the form of (a) possessing books of research, (b) participating in seminars and training, and (c) ability to operate a data processing program, it is known that $64 \%$ of junior high school teachers in Java have all the contributing factors, compared to only $34 \%$ of junior high school teachers in outside of Java. One of the reasons is the location of schools outside of Java which is far away from the city, located on a hill, or even overseas on a different island that requires a 5-hour trip from the district town.

Based on the data above, the junior high school teachers in Java qualitatively have higher levels of the research competence than the junior high school teachers in outside of Java, in all aspects of theoretical mastery, cognitive ability, technical ability, and experience in implementing research.

\section{Conclusion}

Based on the analysis and discussion of the above, the conclusion as follows: there are differences in the levels of competence in the implementation of the research between junior high school Economic-Social Studies teachers in Java and junior high school Economic-Social Studies teachers in outside of Java. The research levels of competence in teachers in Java are higher than those of in outside of Java, in all aspects of theoretical mastery, cognitive ability, technical ability, and experience. Teachers in outside of Java majority (79\%) do not understand the research, so that they will have difficulty in identifying the problems, formulating problems, preparing of theoretical review, data collection, data analysis, and writing a report upon completing research.

Teachers in outside of Java majority (71\%) are categorized poor in the level of technical ability in implementing the research, due to their poor understanding of the research, the lack of reference books and samples of the research projects/reports, while only $37 \%$ of teachers in Java have such difficulties. Limitation in time is one reason for the junior high school teachers both in Java and in outside of Java for not carrying out the research, because most of their time has been allocated for teaching, preparing lesson plans, as well as designing and correcting assignments and exams, moreover for the teachers who get additional duties as the class supervisor, in addition to the difficulty to synchronize the time between the researcher and the collaborators.

\section{Acknowledgements}

In this section may I say thank very much to who provide help during research, especially: (a) Junior High School Economic-Social Studies teachers in Yogyakarta Special Province and in outside of Java, Indonesia, (b) Language Center Yogyakarta State University, (c) Chief of Directorate of Elementary and Secondary Education, Department of Education and Culture Indonesia, (d) Professor Sukirno, Ph.D. from the Faculty of Economics of Yogyakarta State University. 


\section{References}

Arikunto, S. (2012). Prosedur penelitian suatu pendekatan praktek. Jakarta : Rineka Cipta.

Badrun, K. (2011). Kinerja guru profesional (Guru pasca sertifikasi). Jurnal Ilmiah Pendidikan "Cakrawala Pendidikan", 30(3), 470-472.

Depdikbud. (2009). Permeneg PAN \& RB. No. 16 Tahun 2009 tentang. Pengembangan keprofesian berkelanjutan (PKB).

Karia, N., \& Ahmad, Z. A. (2000). Quality practices that pay: Empowerment and teamwork. Malaysian Management Review, 35(2), 66-76.

Kerlinger, F. N., \& Lee, H. (2008). Foundations of behavioral research. Australia: Wadsworth Thomas Learning.

Khotijah, N. (2013). Kinerja guru madrasah dan guru pendidikan agama islam pasca sertifikasi di Sumatera Selatan. Jurnal Ilmiah Pendidikan "Cakrawala Pendidikan”, 32(1), 96.

Kompas, H. U. (2012). Perbaikan kompetensi guru jadi prioritas (p. 9).

Rotich, S. K. et al. (2014). Competence of head teachers in primary school management in Kenya: An evaluation of capacity buliding. Asian Journal of Social Sciwences \& Humanities, 3(2), 131-132.

Sukidjo. (2004). Sikap guru di Daerah Istimewa Yogyakarta terhadap pengembangan profesi. Jurnal Ilmiah Pendidikan "Cakrawala Pendidikan", 33(3), 448-449.

Sukidjo. (2014). Kompetensi penelitian tindakan kelas guru SMP DIY. Jurnal Ilmiah Pendidikan "Cakrawala Pendidikan", 33(3), 376-377.

Suwarjo. (2013). Pendidikan untuk pencerah dan kemandirian bangsa: Kualitas pendidik (guru) Indonesia. Yogyakarta: Ash-Shaft.

Suyanto. (2007). Tantangan profesional guru di era global. Pidato Dies Natalis ke-43 Universitas Negeri Yogyakarta, 21.

Tilaar, H. A. R. (1999). Beberapa agenda reformasi pendidikan nasional: Dalam perspektif abad 21. Magelang: Indonesia Tera.

Undang-undang Republik Indonesia No. 14 Tahun. (2005). Tentang guru dan dosen. Bandung: Nuansa Aulia.

Undang-undang Republik Indonesia No. 20 Tahun. (2003). Tentang sistem pendidikan nasional. Bandung: Nuansa Aulia.

Widoyoko, E. P. (2005). Kompetensi mengajar guru ekonomi SMA Kabupaten Purworejo. Jurnal Ilmiah Pendidikan "Cakrawala Pendidikan”, 24(3), 379-380.

\section{Copyrights}

Copyright for this article is retained by the author(s), with first publication rights granted to the journal.

This is an open-access article distributed under the terms and conditions of the Creative Commons Attribution license (http://creativecommons.org/licenses/by/3.0/). 